- taking into account the special educational needs of preschool children with hearing impairment for the optimal implementation of current and potential opportunities, including cognitive and motivational.

1. Belaya N.A. Psihologo-pedagogcheskiye usloviya razvitiya rechevogo obshsceniya slaboslyshashscih doshkolnikov : diss... . kan. ped. nauk. - M.: 2016. - 186 s.

2. Golovchic L.A. Doshkol'naya surdopedagogika: Vospitanie i obuchenie doshkol'nikov s narusheniyami sluha. - M.: VLADOS, 2001. - 319 s.

3. Goncharova E.L., Kukushkina O.I. Rebenok s osobymi obrazovatel'nymi potrebnostyami//Al'manah Instituta korrekcionnoj pedagogiki RAO. - 2002.- Vyp. №5. - URL: http://almanah.ikprao.ru/articles/almanah-5/rebenok-s-osobymi-obrazovatelnymi-potrebnostjami (data obrashcheniya: 01.03.2019 g.).

4. Evtushenko I.N. Predmetno-razvivayushchaya sreda v doshkol'nom uchrezhdenii i ee diagnostika // Nachal'naya shkola plyus do i posle. - 2008. - № 4. - S. 33-36.

5. Kobrina L.M., Himenkova E.S. Formirovanie rechevoj kommunikacii detej s kohlearnymi implantami v usloviyah special'noj shkoly-internata / Special'noe obrazovanie : materialy XIII mezhdunarodnoj nauchnoprakticheskoj konferencii. 2017. - S. 16-26.

6. Lubovskij V.I. Osobye obrazovatel'nye potrebnosti // Psihologicheskaya nauka i obrazovanie psyedu.ru. 2013. - №5. URL: http://psyedu.ru/journal/2013/5/Lubovskiy.phtml (data obrashcheniya: 12.03.2019 g.).

7. Rechickaya E.G. Korrekcionno-pedagogicheskaya rabota po formirovaniyu uchebnoj deyatel'nosti mladshih shkol'nikov s narusheniem sluha. - M.: VLADOS, 2017.

8. Rechickaya E.G., Gajdova YU.V. Special'naya psihologiya i korrekcionnaya pedagogika: mezhlichnostnye otnosheniya mladshih shkol'nikov s narusheniem sluha. - M.: YUrajt, 2018. - 138 s.

9. Rechickaya E.G., Zurob'yan S.A. Uchebnoe sotrudnichestvo v sisteme obucheniya detej s narusheniyami sluha. - M.: MPGU, 2018. - 192 s.

10. Rechickaya E.G., Kulakova E.V. Gotovnost' slaboslyshashchih detej doshkol'nogo vozrasta k obucheniyu v shkole. - M.: VLADOS, 2014. - 199 s.

11. Rechickaya E.G., Troshkina O.V. Model' korrekcionno-razvivayushchej raboty po formirovaniyu kommunikativno-rechevoj kompetentnosti doshkol'nikov $\mathrm{s}$ narusheniem sluha $\mathrm{v}$ usloviyah igrovoj deyatel'nosti // Nauka i shkola. - 2018. - №3. - S.95-100.

12. Turutina M.A., Denisova O.A., Kazanskaya V.L. Pedagogicheskaya ocenka razvitiya rechevoj kommunikacii u shkol'nikov srednej stupeni obrazovaniya s narusheniem sluha / Special'noe obrazovanie: materialy XIV mezhdunarodnoj nauchno-prakticheskoj konferencii. 2018. - S. 21-24.

13. Federal'nyj zakon «Ob obrazovanii v Rossijskoj Federacii» ot 29.12.2012 № 273-FZ (red. ot 25.12.2018).

\title{
Kozlova N.G. \\ Sociocultural environment and its modeling in a secondary school
}

School Kuzminki

(Russia, Moscow)

doi: 10.18411/scienceconf-05-2019-59

idsp: scienceconf-05-2019-59

\section{Abstract}

In this article numerous approaches to defining the sociocultural environment are studied. The views of the classics of the Russian pedagogy as well as the modern researchers are shown. The definitions of the sociocultural environment from fundamental works and dessertations are being analysed and the author of the article after the deep analysis provides her own definition. The siciocultural environment of a teaching organization and the surroundings of the student are looked at through the prism of personality and qualitative teaching. The relevance of the interest to this issue is underlined. The author provides the personal experience in creating a sociocultural environment in a secondary school.

Key words: sociocultural environment, personality, education quality, operational, competence approach.

The problem of necessity of creating in an educational establishment the sociocultural environment which is aimed at the overall development and upbringing of the student's 
personality is nowadays relevant though rather difficult in the conditions of the educational establishments focusing on the qualitative educational system in which the competence approach is being realized.

The phenomenon of the sociocultural environment became the object of the active scientists' study only at the end of the $20^{\text {th }}$ century and the unified definition of this term by this time has not been formulated. In this respect it is particularly important to comprehend in detail the concept of the environment, the most famous visions and approaches which have predetermined its modern understanding.

In the history of the Russian pedagogical idea development in this direction a significant role has been played by the classics of the Russian pedagogics like V.A. Sukhomlinsky and A.S. Makarenko. So in the works of V.A. Sukhomlinsky the statement about sociocultural environment being the combination of educating the personality means (material and spiritual activity), its conditions (beauty and interaction) and subjects' position (attitude to material and activity spheres and to each other) was concisely formulated [9]. The author of the "Pedagogical Poem" A.S. Makarenko defined the key mechanism of teaching team shaping (sociocultural environment) as the development of responsible dependence relationships. He based his idea on the fact that the establishment of the personality itself is connected with his/her natural ability to perceive the connection with other people and to subordinate his/her life to definite responsibilities. This process in his opinion is the personality's entering into responsible dependence relationships. He wrote: "In order to imagine this problem more clearly, let's look at the team in action. In this team the dependences are rather difficult, each separate personality must coordinate his/her personal intentions with the intentions of the others: first with the aim of the team, second with his/her initial team - the nearest group, must coordinate so that the personal goals do not become antagonistic in relation to the common goals" [6, p. 193].

The general trend in research of sociocultural environment can be traced in the fundamental works, theses and articles in which, first of all, it is noted that the sociocultural environment is multifunctional, multifactored and in its common field it seizes not only professional or everyday, informative or educational space but it penetrates the whole activity of the personality and shapes a definite lifestyle. Herewith, the term "sociocultural environment" itself presupposes two aspects, in the context of which we consider the student's personality establishment: social and cultural [2, p. 44-45].

In terms of this logic the sociocultural environment is being defined as a special socially organized cultural phenomenon in which social and cultural processes are tightly interconnected and interdependent, are developing in the frames of the general idea and influence the activity of the social parties in creation and assimilation of spiritual values and social guidelines [1]. Or it is understood as a particular, directly given to each child social space, by means of which he/she actively incorporates into the cultural relations in the community [8]. Attempts to define sociocultural environment as a specific area are being undertaken [5, p.91.]. However, there is a significant difference between them: in the concept of area unlike in environment, involvement of the person into it is not implied [4, p. 18], meanwhile the environment forms the man and the man forms his/her environment. Moreover, the environment presupposes not only the presence of the person but also mutual influence and interaction of the surroundings with the subject. To add to this, particularly people organize, create the educational environment and affect it in a certain way [7, p.176.]

Significant in the context of the subject matter of sociocultural environment seem the study of pedagogical orientation in which special attention is paid to the possibilities of affecting the personality of the student through teaching particular subjects, creating programs designed in a special way which are connected with shaping the sociocultural environment. In this respect sociocultural educational environment is defined as the area of common vital activity of the teacher and the student which provide the choice of the values, the meaning of life, the environment of the vital activity, ways of cultural self-realisation, and functions on the principles 
of socio-economic determination, cultural causation, information selectiveness and paradigmatics [3], [2, p. 45].

For our research it is also important to note that the modern person is influenced not only by the nearest surroundings (the culture of the family or the social group to which they belong), but also the whole atmosphere of the community life, the way of existence in the world society, its indirect interaction through the books and multimedia meanswith the cultures of different countries and eras. One of the basis of structural analysis can serve the division of all the components of the sociocultural environment into material and spiritual.

Let us look into the specifics of the sociocultural environment of the school which first of all fulfills the teaching and educational functions. In this respect we will note its following characteristics: operational (the presence of mutual activity of the subjects), communicative (appearance of different connections and relations), reflective, value-semantic (vcommon goals, norms, values, meanings of communication and interaction).

So, we can infer that sociocultural environment is a complex of outside conditions of person's stay which with the qualitative work transform into the inner personality's values.

In our school "School Kuzminki" (Moscow, Russia) we have gained substantial experience in sociocultural environment modeling with the help of various work forms and teaching and educational events. In this article we would like to describe our traditional events which create the sociocultural environment of our school. These events have been hold for many years.

Amateur performances - is one of the components of the sociocultural environment and it is being widely developed in "School Kuzminki". Children of different age groups from the kindergarten and school prepare performances, dances, songs both in native and foreign languages, poems timed to various important dates: Teacher's Day, Elderly Person's Day, Mother's Day, New Year, Christmas, Motherland Defender Day, Women's Day, Victory Day, Meeting with the veterans. The concerts are always bright and professionally carried out. Of course the children need an adult help which they get from the teacher-organiser, teacher of music and world cultures, and kindergarten teacher. Moreover, our children prepare the festive programme and perform for the elderly people and children with disabilities. These events teach children to communicate with people of different ages, social position, they teach children to be tolerant, supportive and caring.

In our school we yearly conduct the competition "The Student of the Year". During the year the form teacher sets points in the electronic system created by our system managers specially for our school. The points are for the outward appearance (school uniform), for participation in the Olympiads, for active involvement in the life of the class and the school, for the excellent marks at school during the week. For bad marks during the week the teacher deducts the points. At the end of the school year the points for any 10 weeks are counted and 10 best students in each class are distinguished. Out of these 10 students 2 absolute winners in each class are distinguished. At the end of the school year 10 best students with the greatest number of points are awarded with certificates at the grand meeting and their parents are handed with thank you letters. The absolute winners are invited together with their parents to the festival "The Pride of Our School", where the certificates and the letters are given by the headmaster.

In the year of 2011 in School Kuzminki the student government "Solar System" was started. In this system the students themselves elect the President of the Solar System as well as one representative into the government from each class. Each class is a Solar City and the children are divided into departments: juridical, project, informational, organizational, and statistical - and during the school year each department is responsible for a certain part of the class's life. Every week the meetings are held and the information about the next period is given and the results are announced. For different deeds the students get stars which they stick to their "star sky". At the end of the school year the results are summed up and the best star class is distinguished. The "Solar System" lets unite the children of the whole class and of the whole parallel classes and even of the whole school to become the children of sole planet, sole universe. 
Every February our school conducts Art Festival for which the theme and the regulations are defined at the beginning of the school year. The children prepare a performance on this theme: literary, dancing and singing. This year the theme of the Festival was The Theatrical performances of the world due to the year of the theatre and the previous themes were "May there always be peace" and "How the motherland begins". The performances are assessed in parallels (e.g. all the $7^{\text {th }}$ forms). This festival helps not only nurture a sense of beauty but also active civic stand and the feeling of patriotism.

The competition Historical Reading also helps develop the feeling of patriotism. The representatives from each class prepare a presentation about the war heroes and deliver it in certain costumes to the judges. The judges are the teachers of art and culture, music, teachersorganizers. The best school representations then go to district and municipal level.

The Days of Health and Sport Festivals organized at the school during weekends also contribute to nurturing the active civic stand. The children come for these events with pleasure and bring their parents and take part in relay race, marathons, contests and competitions.

A special attention at our school is paid to the school leavers homecoming night. The school leavers of different years are invited for the meeting with the headmaster and the teachers. It is always pleasant for the students that they are remembered and waited in the walls of their native school. The teachers always listen with interest to the stories about the life of the school leavers and tell them the news from the school life.

At the end of the school year we arrange the last bell ringing event for the school leavers of Year 9 and Year 11. The school leavers prepare a festive programme for the teachers, the teachers make farewell speeches on the eve of the exams. It is notable that in School Kuzminki not only the teachers who have been working with these students from Year 1 to Year 11 (secondary school teachers and primary school teachers) are invited to this festival, but also the teachers who already do not work at the school for some reason.

Participation in public events: our students actively participate in different public events like Collect plastic lids, or Make a postcard for the New Year for the elderly people from the retirement homes, or Present veterans and elderly people with flowers and postcards for the Victory Day, or Make a souvenir ffor elderly people for Elderly Person's Day.

It is important to point out that at our school children of different social levels as well as children of different nationalities study. The teachers nurture in the children the feeling of tolerance and create the atmosphere of amicability and comfortable psychological climate.

All the events in creating the sociocultural environment in School Kuzminki described provide the children with great social experience, teach communicating with people of different professions, age groups and rules of conduct and serve as a powerful upbringing factor.

As we can see from the events described in School Kuzminki the most favorable conditions for nurturing patriotism, active civic stand, tolerance and patience are created. The children are attached to the sense of beauty and the cultural life of the school as well as of the city and the country.

$$
* * *
$$

1. Arnoldov A.I. Введение в культурологию. - М.: Народная академия культуры и общечеловеческих ценностей, 1993. - $352 \mathrm{pp}$.

2. Burdukovskaya Е.А. Социокультурная среда вуза как педагогический фактор личностного становления студента. Дисс.Канд.пед.наук. Благовещенск, 2004. - 201 pp., p. 44-45.

3. Ignatova V.V. Педагогические факторы духовно-творческого становления личности в процессе социализации и условия их реализации: Дис... д-ра пед. наук / Челябинский государственный университет (ЧелГУ), 2001.- 365 рр.

4. Krivykh S.V. Соотношение понятий «Среда» и «Пространство» в социокультурном и образовательном аспектах // Известия АлтГУ. 2010. №1-2. - Р. 18.

5. Krylova N.B. Социокультурная среда // Новые ценности образования: Тезаурус... -Вып. 1. - М., 1995.- p.91.

6. Makarenko A.S. Педагогические сочинения. В 8-ми томах. Т.4. - М.: Педагогика, 1986. - 399 рр., p. 193. 
7. Nenakhova E.N. Теоретико-методологические подходы к формированию социокультурного пространства образовательного учреждения // Известия РГПУ им. А.И. Герцена. 2010. №128. p.176.

8. Nitssche F. Сочинения: В 2 т. / Ф. Ницше. - М., 1990. - Т.2 - 830 pp.

9. Sukhomlinskiy V.A. Избранные педагогические сочинения: В 3-х т. Т.З/Сост.О.С.Богданова, В.3.Смаль.-М.: Педагогика, 1981.-640 pp. 